\title{
PERBEDAAN KEMAMPUAN PEMAHAMAN KONSEP MATEMATIKA SISWA DENGAN MODEL PEMBELAJARAN KONTEKSTUAL DAN MODEL PEMBELAJARAN INVESTIGASI KELOMPOK KELAS VIII SMP NEGERI 1 PANCUR BATU
}

\author{
${ }^{1}$ Arif Pribadi, ${ }^{2}$ Humuntal Banjarnahor \\ ${ }^{1}$ Fakultas Matematika dan Ilmu Pengetahuan Alam, Universitas Negeri Medan \\ ${ }^{2}$ Dosen Fakultas Matematika dan Ilmu Pengetahuan Alam, Universitas Negeri Medan \\ Email: arifpribadisdk@gmail.com
}

\begin{abstract}
ABSTRAK
Penelitian ini bertujuan untuk melihat bahwa kemampuan pemahaman konsep matematika siswa menggunakan model pembelajaran kontekstual (CTL) lebih baik daripada menggunakan model pembelajaran investigasi kelompok (Group Investigation) di kelas VIII SMP Negeri Pancur Batu. Jenis penelitian ini adalah eksperimen semu. Populasi dalam penelitian ini adalah seluruh kelas VIII SMP Negeri 1 Pancur Batu yang terdiri dari 7 kelas. Pengambilan sampel dilakukan dengan menggunakan purposive sampling dan diambil kelas VIII-6 sebagai kelas eksperimen 1 dengan 34 siswa, serta kelas VIII-7 sebagai kelas eksperimen 2 dengan 32 siswa. Penelitian ini menggunakan intrumen berbentuk uraian yaitu posttest yang digunakan untuk mengetahui kemampuan pemahaman konsep matematika siswa. Dari hasil penelitian setelah diberikan perlakuan berbeda yaitu kelas eksperimen 1 menggunakan model pembelajaran kontekstual (CTL) dan kelas eksperimen 2 menggunakan model pembelajaran investigasi kelompok (Group Investigation) diperoleh nilai rata-rata 77,171 untuk kelas eksperimen 1 dan 70,685 untuk kelas eksperimen 2. Hasil uji hipotesis memberikan nilai thitung $=$ 1,734252 dan $t_{\text {tabel }}=1,6693$ dengan $d k=64$ dan taraf signifikan $\alpha=0,05$ sehingga terlihat $t_{\text {hitung }}(1,734252)>t_{\text {tabel }}(1,6693)$ yang berarti bahwa $H_{o}$ ditolak dan $H_{a}$ diterima. Sehingga disimpulkan bahwa kemampuan pemahaman konsep matematika siswa yang diajar menggunakan model pembelajaran kontekstual (CTL) lebih tinggi daripada kemampuan pemahaman konsep matematika siswa yang diajar menggunakan model pembelajaran Investigasi Kelompok (Group Investigation).
\end{abstract}

Kata Kunci : Pemahaman Konsep Matematika Siswa, Model Pembelajaran Konteskstual (CTL), Model Pembelajaran Investigasi Kelompok.

\begin{abstract}
This study aims to see that the ability to understand students' mathematical concepts using contextual learning model (CTL) is better than using Group Investigation model in Grade VIII SMP Negeri Pancur Batu. This type of research is a quasi experiment. The population in this study is the entire class VIII SMP Negeri 1 Pancur Batu which consists of 7 classes. Sampling was done by using purposive sampling and taken class VIII-6 as experiment class 1 with 34 students, and class VIII-7 as experiment class 2 with 32 students. This study uses the intrument in the form of a description of posttest used to determine the ability to understand the concept of mathematics students. From the result of the research after being given different treatment that is experiment class 1 using contextual learning model (CTL) and experimental class 2 using

Arif Pribadi, Humuntal Banjarnahor. Perbedaan Kemampuan Pemahaman Konsep Matematika Siswa dengan Model Pembelajaran Kontekstual dan Model Pembelajaran Investigasi Kelompok Kelas VIII SMP Negeri 1 Pancur Batu. Jurnal Inspiratif, Vol. 3 No. 3 Desember 2017.
\end{abstract}


Group Investigation study model obtained the average value 77,171 for experiment class 1 and 70,685 for experiment class 2. Test result Hypothesis gives tcount $=1,734252$ and ttable $=$ 1,6693 with $d k=64$ and significant level $a=0.05$ so it looks t_hitung (1.734252)>t_tabel (1,6693) which means that Ho is rejected and Ha accepted. It is concluded that the students' understanding of mathematical concepts taught using contextual learning model (CTL) is higher than the ability to comprehend the concepts of mathematics students taught using Group Investigation model.

Keywords: Understanding Mathematical Concept, Contextual Learning Model (CTL), Model of Group Investigation Learning.

\section{PENDAHULUAN}

Matematika sekolah mempunyai peranan penting dalam upaya penguasaan ilmu dan teknologi. Sehingga, untuk dapat menguasai dan menciptakan teknologi serta bertahan di masa depan diperlukan penguasaan matematika yang kuat sejak dini. Hal ini sejalan dengan pendapat Susanto (2014: 185) yang menyatakan "Matematika merupakan salah satu disiplin ilmu yang dapat meningkatkan kemampuan berpikir dan berargumentasi, memberikan kontribusi dalam penyelesaian masalah sehari-hari dan dalam dunia kerja, serta memberikan dukunan dalam pengembangan ilmu pengetahuan dan teknologi”.

Pemahaman konsep merupakan salah satu faktor tercapainya tujuan pembelajaran. Selain itu, pemahaman konsep matematika merupakan landasan penting untuk berpikir dalam menyelesaikan permasalahan dalam materi matematika maupun dalam menyelesaikan permasalahan dalam kehidupan sehari-hari. Oleh karena itu, kemampuan pemahaman konsep matematis menjadi salah satu tujuan penting dalam pembelajaran matematika. Seperti yang dinyatakan Zulkardi dalam Murizal (2002: 20) bahwa "mata pelajaran matematika menekankan pada konsep". Artinya dalam mempelajari matematika peserta didik harus memahami konsep matematika terlebih dahulu agar dapat menyelesaikan soal-soal dan mampu mengaplikasikan pembelajaran tersebut di dunia nyata dan mampu mengembangkan kemampuan lain yang menjadi tujuan dari pembelajaran matematika. Pemahaman terhadap konsep-konsep matematika merupakan dasar untuk belajar matematika secara bermakna.

Wardani (2008: 10-11) menyatakan bahwa indikator dalam pemahaman konsep menurut Peraturan Dirjen Depdiknas Nomor 506/C/Kep/PP/2004 tanggal 11 November 2004 tentang rapor pernah diuraikan bahwa indikator siswa memahami konsep matematika adalah mampu: 1) Menyatakan ulang sebuah konsep; 2) Mengklasifikasikan objek menurut sifatsifat tertentu sesuai dengan konsepnya; 3) Memberi contoh dan bukan contoh; 4) Menyajikan konsep dalam berbagai bentuk representasi matematis; 5) Mengembangkan syarat perlu atau syarat cukup dari suatu konsep; 6) Menggunakan dan memanfaatkan serta memilih prosedur atau operasi tertentu; 7) Mengaplikasikan konsep atau algoritma pada pemecahan masalah. Sedangkan menurut NCTM dalam Murizal (2012 : 19) untuk mengetahui pengetahuan dan pemahaman siswa terhadap konsep matematika dapat dilihat dari kemampuan siswa dalam: 1) mendefinisikan konsep secara verbal dan tulisan; 2) mengidentifikasi dan membuat contoh dan bukan contoh; 3) menggunakan

Arif Pribadi, Humuntal Banjarnahor. Perbedaan Kemampuan Pemahaman Konsep Matematika Siswa dengan Model Pembelajaran Kontekstual dan Model Pembelajaran Investigasi Kelompok Kelas VIII SMP Negeri 1 Pancur Batu. Jurnal Inspiratif, Vol. 3 No. 3 Desember 2017. 
model, diagram dan simbol-simbol untuk merepresentasikan sesuatu; 4) mengubah suatu bentuk representasi ke bentuk lainnya; 5) mengenal berbagai makna dan interpretasi konsep; 6) mengidentifikasi sifat-sifat suatu konsep dan mengenal syarat yang menentukan suatu konsep; 7) membandingkan dan membedakan konsepkonsep.

Untuk keperluan penelitian, peneliti mengambil indikator pemahaman konsep tersebut menjadi lima indikator yang merupakan irisan dari indikator-indikator yang telah disebutkan di atas, yaitu :

1. Menyatakan ulang sebuah konsep,

2. Memberikan contoh dan bukan contoh,

3. Menyajikan konsep dalam berbagai bentuk representasi matematis,

4. Menggunakan prosedur atau operasi tertentu,

5. Mengaplikasikan konsep atau algoritma ke pemecahan masalah

$$
\text { Meskipun kemampuan }
$$

pemahaman konsep matematika siswa sangat penting, tetapi tingkat kemampuan pemahaman konsep matematika siswa masih sangat rendah. Hal ini dapat dilihat dari hasil tes PISA (Programme for International Student Assessment), dimana keikutsertaan Indonesia dalam tes PISA pada tahun 2003, 2006, 2009 dan 2012 memperoleh hasil yang kurang memuaskan. Pada tahun 2003, dalam bidang matematika, Indonesia berada di peringkat 38 dari 41 negara dengan rataan skor 260 dari rataan skor internasional 496. Pada tahun 2006 rataan skor naik menjadi 391 dengan peringkat 50 dari 57 negara. Pada tahun 2009 Indonesia menempati peringkar 61 dari 65 negara dengan rataan turun menjadi 371. Pada tahun 2012 Indonesia berada di peringkat 64 dari 65, hanya unggul dari negara Peru dengan skor 375 (Wulandari, dkk, 2015: 11).
Terdapat banyak hal yang menjadi penyebab sulitnya siswa dalam memahami konsep matematika. Salah satunya adalah penerapan model atau metode pembelajaran yang tidak sesuai atau terkesan monoton baik dalam menyampaikan materi yang diajarkan maupun cara pembelajarannya, maupun metode pembelajarannya yang tidak bervariasi, sehingga siswa menjadi tidak senang dan merasa bosan dalam mempelajari matematika. Surya, dkk. (2013) mengemukakan bahwa kesulitan yang diperoleh siswa adalah pada saat memahami, menggambar diagram, membaca grafik dengan benar, pemahaman konsep matematika formal, dan penyelesaian masalah matematika. Penyajian masalah yang tepat adalah hal mendasar dalam memahami masalah tersebut dan membuat rencana untuk menyelesaikannya. Sejalan dengan itu Effendi (2012: 3) menyebutkan bahwa:

"Pada umumnya siswa mempelajari matematika hanya diberi tahu oleh gurunya dan bukan melalui kegiatan eksplorasi. Itu semua mengindikasikan bahwa siswa tidak aktif dalam belajar. Melalui proses pembelajaran seperti ini, kecil kemungkinan kemampuan matematis siswa dapat berkembang."

Oleh karena itu pendidik harus mengusahakan agar siswa mencapai hasil yang optimal dalam menguasai keterampilan pemahaman konsep. Berbagai upaya dapat diusahakan oleh pengajar, diantaranya dapat dengan memberikan media pembelajaran yang baik, atau dengan memberikan model pembelajaran yang sesuai.

Pemilihan model pembelajaran
yang bervariasi akan membantu
meningkatkan kegiatan belajar mengajar
dan menumbuhkan motivasi siswa untuk
belajar. Agar siswa dapat belajar dengan
baik, maka model mengajar harus
diusahakan seefisien dan seefektif mungkin.
Dalam perkembangan dunia pendidikan
terdapat beberapa model pembelajaran yang

Pemilihan model pembelajaran yang bervariasi akan membantu meningkatkan kegiatan belajar mengajar dan menumbuhkan motivasi siswa untuk belajar. Agar siswa dapat belajar dengan baik, maka model mengajar harus diusahakan seefisien dan seefektif mungkin. terdapat beberapa model pembelajaran yang

Arif Pribadi, Humuntal Banjarnahor. Perbedaan Kemampuan Pemahaman Konsep Matematika Siswa dengan Model Pembelajaran Kontekstual dan Model Pembelajaran Investigasi Kelompok Kelas VIII SMP Negeri 1 Pancur Batu. Jurnal Inspiratif, Vol. 3 No. 3 Desember 2017. 
tepat untuk meningkatkan pemahaman konsep siswa, diantaranya adalah model pembelajaran kontekstual (Contextual Teaching and Learning) dan model pembelajaran investigasi kelompok (Group Investigation).

Pengajaran dan pembelajaran kontekstual atau contextual teaching and learning (CTL) merupakan suatu konsepsi yang membantu guru mengaitkan konten mata pelajaran dengan situasi dunia nyata, dan memotivasi siswa membuat hubungan antara pengetahuan dan penerapannya dalam kehidupan mereka sebagai anggota keluarga, warga negara dan tenaga kerja (Trianto. 2014 : 138). Pembelajaran kontekstual dapat dikatakan sebagai suatu pembelajaran yang mengakui dan menunjukkan kondisi alamiah dari pengetahuan. Jika siswa mempelajari materi pelajaran yang disajikan melalui konteks kehidupan mereka dan menemukan arti sendiri di dalam proses pembelajaran, maka materi pelajaran akan tambah berarti dan menyenangkan.

Dalam pembelajaran kontekstual, siswa diajak untuk mengaktifkan pengetahuan yang sudah ada pada dirinya (activating knowledge). Kemudian siswa menambah pengetahuan baru (acquiring knowledge) dengan cara deduktif, yaitu mempelajari secara keseluruhan, kemudian memperhatikan detailnya. Selanjutnya siswa memahami pengetahuan (understanding knowledge), artinya siswa tidak menghafal materi ataupun rumusrumus, melainkan memahaminya. Setelah itu siswa mempraktikkan pengetahuan dan pengalaman tersebut (applying knowledge) sehingga tampak perubahan perilaku siswa, dan terakhir melakukan refleksi (reflecting knowledge) sebagai proses perbaikan.

Sementara itu model pembelajaran investigasi kelompok (Group Investigation) merupakan salah satu bentuk pembelajaran kooperatif yang menekankan pada partisipasi dan aktivitas siswa untuk mencari sendiri informasi pelajaran yang akan dipelajari melalui bahan-bahan yang tersedia (Faturrohman. 2015: 69). Dalam model pembelajaran investigasi kelompok, siswa dibagi menjadi beberapa kelompok (grouping), lalu kemudian merencanakan (planning) tugas-tugas, kerja sama dan lainlain. Setelah itu siswa melakukan penyelidikan terhadap permasalahan (investigation), lalu pengorganisasian (organizing), menganalisis dan menyintesis informasi yang diperoleh. Setelah semuanya dilakukan, barulah siswa diminta untuk mempresentasikan hasil investigasinya (presenting). Dan di akhir, barulah diadakan evaluasi (evaluation) yaitu penilaian hasil kerja.

Pada model pembelajaran investigasi kelompok ini siswa diajak untuk menumbuhkan kemampuan berpikir mandiri. Karena dalam model pembelajaran ini siswa dituntut untuk terlibat secara aktif mulai dari tahap pertama sampai akhir pembelajaran. Selain itu, model pembelajaran investigasi kelompok ini juga menuntut siswa untuk memiliki kemampuan yang baik dalam berkomunikasi, serta keterampilan proses dalam berkelompok.

Berdasarkan uraian di atas, permasalahan yang akan dikaji dalam penelitian ini adalah bagaimana perbedaan kemampuan pemahaman konsep matematika siswa yang diajar dengan menggunakan model pembelajaran kontekstual dan model pembelajaran investigasi kelompok.

\section{METODE PENELITIAN}

Jenis penelitian yang digunakan dalam penelitian ini adalah metode kuasi eksperimen atau eksperimen semu, yaitu penelitian yang dimaksudkan untuk mengetahui ada tidaknya akibat dari sesuatu

Arif Pribadi, Humuntal Banjarnahor. Perbedaan Kemampuan Pemahaman Konsep Matematika Siswa dengan Model Pembelajaran Kontekstual dan Model Pembelajaran Investigasi Kelompok Kelas VIII SMP Negeri 1 Pancur Batu. Jurnal Inspiratif, Vol. 3 No. 3 Desember 2017. 
yang dikenakan pada subjek, dalam hal ini adalah siswa, dan dikatakan eksperimen semu sebab kondisi-kondisi siswa tidak dapat dikontrol secara keseluruhan. Penelitian ini melibatkan dua kelas, yaitu kelas eksperimen 1 yang diberi perlakuan yaitu pengajaran materi kubus dan balok menggunakan model pembelajaran kontekstual, sedangkan pada kelas eksperimen 2 diberi perlakuan pembelajaran dengan model pembelajaran investigasi kelompok (group investigation).

\section{Populasi dan Sampel}

Populasi dalam penelitian ini adalah seluruh kelas VIII SMP Negeri 1 Pancur Batu Tahun Ajaran 2016/2017 yang terdiri dari tujuh kelas dan memiliki siswa sebanyak 235 siswa. Sementara sampel pada penelitian ini adalah kelas VIII-6 sebagai kelas eksperimen A yang menggunakan model pembelajaran kontekstual (CTL) dan kelas VIII-7 sebagai kelas eksperimen B yang menggunakan model pembelajaran investigasi kelompok (group investigation). Kelas VIII-6 terdiri dari 34 siswa, sedangkan kelas VIII-7 terdiri dari 30 siswa.

\section{Instrumen Penelitian}

Instrumen penelitian yang digunakan dalam penelitian ini adalah berupa tes. Tes digunakan untuk mengetahui tingkatan kemampuan matematika siswa. Tes ini diberikan sesudah diberikan perlakuan pembelajaran dengan bentuk tes yang diberikan berupa post-test sebanyak 6 soal.

Untuk keberartian harga validitas tiap item maka harga tersebut dikonfirmasikan ke dalam tabel ke harga kritik moment dengan kriteria soal valid jika $r_{\text {hitung }}>r_{\text {tabel }}$. untuk $\mathrm{N}=32$ dan $\alpha=$ 0,05 maka diperoleh $r_{\text {tabel }}=0,349$. Dengan membandingkan $r_{\text {hitung }}=0,5998$ terhadap $r_{\text {tabel }}=0,349$ ternyata $r_{\text {hitung }}>r_{\text {tabel }}$, maka soal tersebut valid. Dengan menggunakan cara yang sama, kita dapat melihat validitas dari keenam butir tes, dan hasilnya diperoleh bahwa seluruh soal dinyatakan valid.

Sementara untuk reliabilitas tes, diperoleh $r_{\text {hitung }}=0,5779$ dan $r_{\text {tabel }}=0,349$ dengan $\mathrm{N}=38$ dan $\alpha=0,05$. Dengan membandingkan $r_{\text {hitung }}$ dan $r_{\text {tabel }}$ ternyata $r_{\text {hitung }}>r_{\text {tabel }}(0,5779>0,349)$, maka soal tersebut reliabel. Berdasarkan kriteria pengukuran reliabilitas tes, maka soal tersebut mempunyai tingkat reliabilitas sedang.

\section{HASIL PENELITIAN DAN PEMBAHASAN}

Dari hasil posttest pemahaman konsep matematika yang diperoleh pada kelas eksperimen 1 dan kelas eksperimen 2 secara ringkas disajikan dalam tabel 1

Tabel 1. Data Posttest Kelas Eksperimen 1 dan Kelas eksperimen 2

\begin{tabular}{|c|c|c|}
\hline \multirow{2}{*}{ Statistik } & \multicolumn{2}{|c|}{ Kelas } \\
\cline { 2 - 3 } & Eksperimen 1 & Eksperimen 2 \\
\hline Jumlah Siswa & 34 & 32 \\
\hline Nilai Maksimum $\left(X_{\text {maks }}\right)$ & 95,24 & 92,86 \\
\hline Nilai Minimum $\left(X_{\text {min }}\right)$ & 42,86 & 40,48 \\
\hline Rata- Rata & 77,171 & 70,685 \\
\hline Simpangan Baku & 15,219 & 15,149 \\
\hline
\end{tabular}

Tabel 1. menunjukkan data pada kelas eksperimen 1 dan kelas eksperimen 2 setelah dilakukan proses pembelajaran dengan model pembelajaran kontekstual (CTL) dan model pembelajaran investigasi

Arif Pribadi, Humuntal Banjarnahor. Perbedaan Kemampuan Pemahaman Konsep Matematika Siswa dengan Model Pembelajaran Kontekstual dan Model Pembelajaran Investigasi Kelompok Kelas VIII SMP Negeri 1 Pancur Batu. Jurnal Inspiratif, Vol. 3 No. 3 Desember 2017. 
kelompok (Group Investigation). Kedua kelas memiliki Rentang nilai yang sama yaitu 52,38. Nilai siswa tertinggi dari dua kelas tersebut terdapat pada kelas eksperimen 1 dengan nilai 95,24. Artinya pemahaman konsep matematika perorangan tertinggi terdapat di kelas eksperimen 1.

Pemahaman konsep dalam penelitian ini didasarkan pada lima indikator, yaitu 1) menyatakan ulang sebuah konsep; 2) memberi contoh dan bukan contoh; 3) menyajikan konsep ke dalam bentuk representasi matematis; 4) Menggunakan algoritma atau operasi tertentu; dan 5) mengaplikasikan konsep ke dalam pemecahan masalah. Skor pemahaman konsep matematika siswa pada kelas eksperimen 1 dan kelas eksperimen 2 berdasarkan indikator disajikan dalam Tabel 2.

Tabel 2. Nilai dan Skor Posttest Berdasarkan Indikator

\begin{tabular}{|c|c|c|c|c|c|c|c|c|}
\hline \multirow[b]{2}{*}{ No } & \multirow[b]{2}{*}{ Indikator } & \multirow[b]{2}{*}{$\begin{array}{l}\text { Skor } \\
\text { Ideal }\end{array}$} & \multicolumn{3}{|c|}{ Kelas Eksperimen 1} & \multicolumn{3}{|c|}{ Kelas Eksperimen 2} \\
\hline & & & $\begin{array}{l}\text { Skor } \\
\text { Rata- } \\
\text { Rata }\end{array}$ & $\begin{array}{l}\text { Nilai } \\
\text { Rata- } \\
\text { Rata }\end{array}$ & Ket & $\begin{array}{l}\text { Skor } \\
\text { Rata- } \\
\text { Rata }\end{array}$ & $\begin{array}{l}\text { Nilai } \\
\text { Rata- } \\
\text { Rata }\end{array}$ & Ket \\
\hline 1 & $\begin{array}{c}\text { Menyatakan Ulang } \\
\text { Konsep }\end{array}$ & 8 & 5,97 & 74.63 & Baik & 5,72 & 71.50 & Baik \\
\hline 2 & $\begin{array}{l}\text { Memberi contoh } \\
\text { dan bukan contoh }\end{array}$ & 10 & 7,97 & 79.70 & Baik & 7,12 & 71.20 & Baik \\
\hline 3 & Menyajikan konsep & 6 & 4,79 & 79.83 & Baik & 4,59 & 76.50 & Baik \\
\hline 4 & $\begin{array}{l}\text { Menggunakan } \\
\text { prosedur }\end{array}$ & 12 & 9,35 & 77.92 & Baik & 8,09 & 67.42 & Cukup \\
\hline 5 & $\begin{array}{l}\text { Mengaplikasikan } \\
\text { konsep }\end{array}$ & 6 & 4,35 & 72.50 & Baik & 4,16 & 69.33 & Cukup \\
\hline
\end{tabular}

Pada kelas eksperimen 1, nilai rata-rata indikator menyajikan konsep ke berbagai bentuk representasi matematik lebih tinggi dibandingkan keempat indikator lainnya, yaitu 79,83. Nilai ratarata indikator tertinggi selanjutnya adalah pada indikator memberikan contoh dan bukan contoh, yaitu 79,70. Hal ini menunjukkan bahwa sebagian siswa sudah cakap dalam menyajikan konsep ke berbagai bentuk representasi matematik, serta memberikan contoh dan bukan contoh. Sedangkan nilai rata-rata indikator terendah adalah indikator mengaplikasikan konsep ke bentuk pemecahan masalah, yaitu 72,50. Dari nilai tersebut, keseluruhan nilai rata-rata tiap indikator pemahaman konsep matematika pada kelas eksperimen 1 berada pada rentang 70,00 84,99. Artinya, dapat diinterpretasikan bahwa kemampuan pemahaman konsep matematika kelas eksperimen 1 tergolong baik.

Pada kelas eksperimen 2, nilai rata-rata indikator menyajikan konsep ke berbagai bentuk representasi matematik lebih tinggi dibandingkan keempat indikator lainnya, yaitu 76,50. Nilai ratarata indikator tertinggi selanjutnya adalah menyatakan ulang sebuah konsep yaitu 71,50 serta memberi contoh dan bukan contoh yaitu 71.20. Hal ini menunjukkan bahwa untuk ketiga indikator tersebut di kelas eksperimen 2 tergolong baik. Sedangkan untuk nilai rata-rata indikator menggunakan prosedur atau operasi tertentu dan mengaplikasikan konsep ke pemecahan masalah masing-masing adalah 67,42 dan 69,33. Hal ini menunjukkan bahwa untuk indikator menggunakan

Arif Pribadi, Humuntal Banjarnahor. Perbedaan Kemampuan Pemahaman Konsep Matematika Siswa dengan Model Pembelajaran Kontekstual dan Model Pembelajaran Investigasi Kelompok Kelas VIII SMP Negeri 1 Pancur Batu. Jurnal Inspiratif, Vol. 3 No. 3 Desember 2017. 
prosedur atau operasi tertentu dan mengaplikasikan konsep ke pemecahan masalah pada kelas eksperimen 2 tergolong cukup.

Uji normalitas data dilakukan untuk mengetahui apakah populasi yang digunakan berdistribusi normal atau tidak.
Uji normalitas data dilakukan dengan menggunakan uji Liliefors dengan syarat normal adalah $\mathrm{L}_{0}<\mathrm{L}_{\text {tabel }}$ pada taraf $\alpha=$ 0,05 . Secara ringkas hasil pehitungan uji normalitas data posttest pada masingmasing kelas dapat dilihat pada Tabel 3

Tabel 3. Ringkasan Uji Normalitas Data Posttest Siswa

\begin{tabular}{|c|c|c|c|c|}
\hline Data & Kelas & $\mathrm{L}_{0}$ & $\mathrm{~L}_{\text {tabel }}(\alpha=0,05)$ & Kesimpulan \\
\hline 34 & Eksperimen 1 & 0,1170 & 0,1519 & Normal \\
\hline 32 & Eksperimen 2 & 0,1270 & 0,1519 & Normal \\
\hline
\end{tabular}

Dari tabel di atas terlihat bahwa hasil uji normalitas pada taraf signifikansi $\alpha$ $=0,05$ menunjukkan data posttest dari kedua sampel memiliki sebaran data yang berdistribusi normal. Hal ini diperoleh dengan membandingkan nilai signifikansi hasil perhitungan dengan $\alpha$ yang telah ditetapkan. Nilai signifikansi tes pemahaman konsep matematika siswa pada kelas eksperimen $1 \mathrm{~L}_{0}(0,1170)<\mathrm{L}_{\text {tabel }}$ $(0,1519)$ ini berarti data berdistribusi normal dan pada kelas eksperimen $2 \mathrm{~L}_{0}$ $(0,1270)<\mathrm{L}_{\text {tabel }}(0,1519)$ maka data berdistribusi normal. Hal ini menunjukkan bahwa nilai signifikansi tes pemahaman konsep matematika siswa pada kedua kelas tersebut (eksperimen $1=0,1170$ dan eksperimen $2=0,1270$ ) lebih tinggi daripada nilai kritis untuk uji Liliefors harga $\mathrm{L}_{\text {tabel }}=0,1519$ dengan $\alpha=0,05$ dan $\mathrm{n}_{1}$ $=34$ dan $\mathrm{n}_{2}=32$ sehingga disimpulkan bahwa data posttest pemahaman konsep matematika siswa pada populasi berdistribusi normal.

Hasil perhitungan uji homogenitas data dengan menggunakan uji F. Jika $F_{\text {hitung }}$ $\geq \mathrm{F}_{\text {tabel }}$ maka $\mathrm{H}_{0}$ ditolak atau kedua varians berbeda. Sedangkan jika $F_{\text {hitung }}<\mathrm{F}_{\text {tabel }}$ maka $\mathrm{H}_{0}$ diterima atau kedua varians homogen. Dengan derajat kebebasan pembilang $=33$ dan derajat kebebasan penyebut $=31$ serta taraf nyata $\alpha=0,05$. Ringkasan hasil uji homogenitas disajikan pada tabel 4

Tabel 4. Ringkasan Perhitungan Uji Homogenitas

\begin{tabular}{|c|c|c|c|c|}
\hline Kelas & Varians & $\mathrm{F}_{\text {hitung }}$ & $\mathrm{F}_{\text {tabel }}$ & Kesimpulan \\
\hline Eksperimen 1 & 231,608 & \multirow{2}{*}{1,00928} & 1,44 & Homogen \\
\hline Eksperimen 2 & 229,478 & & & \\
\hline
\end{tabular}

$\mathrm{F}_{\text {hitung }}(1,00928)<\mathrm{F}_{\text {tabel }}(1,44)$. Hal ini menunjukkan varians nilai pemahaman konsep matematika siswa pada populasi adalah homogen.

\section{Uji Hipotesis}

$$
\text { Pengujian normalitas dan } \mathrm{H}_{\mathrm{a}}: \mu_{1}>\mu_{2}
$$

homogenitas telah menunjukkan bahwa Keterangan:
data posttest pemahaman konsep matematika pada populasi berdistribusi

Arif Pribadi, Humuntal Banjarnahor. Perbedaan Kemampuan Pemahaman Konsep Matematika Siswa dengan Model Pembelajaran Kontekstual dan Model Pembelajaran Investigasi Kelompok Kelas VIII SMP Negeri 1 Pancur Batu. Jurnal Inspiratif, Vol. 3 No. 3 Desember 2017. 
$\mu_{1}: \quad$ Rata - rata nilai postest siswa yang diajar dengan menggunakan model pembelajaran kontekstual (CTL)

$\mu_{2}$ : Rata - rata nilai postest siswa yang diajar dengan menggunakan model pembelajaran Group Investigation (GI)
Setelah diberikan perlakuan maka diperoleh nilai posttest kelas eksperimen 1 dengan nilai rata-rata 77,171 dan nilai posttest kelas eksperimen 2 dengan nilai rata-rata 70,685. Ringkasan perhitungan uji hipotesis kelas eksperimen 1 dan kelas eksperimen 2 ditunjukkan pada Tabel 5.

Tabel 5. Ringkasan Perhitungan Uji Hipotesis Data Posttest

\begin{tabular}{|c|c|c|c|c|c|}
\hline \multirow{3}{*}{ Uji t } & Data Kelas & $\begin{array}{c}\text { Nilai Rata- } \\
\text { Rata }\end{array}$ & $\mathrm{t}_{\text {hitung }}$ & $\mathrm{t}_{\text {tabel }}$ & Kesimpulan \\
\hline & Eksperimen 1 & 77,171 & \multirow{2}{*}{1,734252} & \multirow{2}{*}{1,66493} & \multirow{2}{*}{ Tolak $\mathrm{H}_{0}$} \\
\hline & Eksperimen 2 & 70,685 & & & \\
\hline
\end{tabular}

Berdasarkan tabel 4.5. di atas hasil pengujian pada taraf signifikansi $\alpha=$ 0,05 dan $\mathrm{dk}=34+32-2=64$ dengan $\mathrm{t}_{\text {hitung }}$ $=1,734252$ dan $t_{\text {tabel }}=1,6693$ sehingga terlihat $\quad t_{\text {hitung }}(1,734252)>$ $t_{\text {tabel }}(1,6693)$ yang berarti bahwa $\mathrm{H}_{\mathrm{o}}$ ditolak dan $\mathrm{H}_{\mathrm{a}}$ diterima. Sehingga disimpulkan bahwa kemampuan pemahaman konsep matematika siswa yang diajar dengan menggunakan model pembelajaran kontekstual (CTL) lebih baik dibandingkan pemahaman konsep matematika siswa yang diajar dengan menggunakan model pembelajaran investigasi kelompok (Group Investigation) di kelas VIII SMP Negeri 1 Pancur Batu.

Pemahaman konsep yang diajar dengan menggunakan model pembelajaran kontekstual pada aspek masyarakat belajar, siswa saling sharing bertukar pendapat, ide dan penyelesaian sehingga kemampuan pemahaman konsep siswa bisa sama atau relatif sama pada setiap kelompok. Guru sebagai fasilitator dan schaffolding pada saat pembelajaran harus dapat membuat suasana pembelajaran hidup dan menyenangkan. Temuan Surya (2013) mengemukakan bahwa pembelajaran tidak seperti yang diharapkan akibat faktor guru, antara lain : a) masih ada guru yang pendidikannya tidak sesuai dengan mata pelajaran, b) penguasaan guru terhadap materi matematika yang diajarkan masih sangat rendah. Hal ini dapat dilihat dari hasil probing test guru yang menunjukkan masih terdapat guru yang hanya menguasai $40 \%$ dari probing test yang dilakukan, c) Guru kurang menguasai materi pembelajaran secata menyeluruh. Hal ini berdasarkan masukan dari angket siswa yang menyatakan bahwa siswa sulit memahami pelajaran yang diberikan guru. Guru seharusnya melibatkan siswa secara aktif dalam belajar tidak hanya ceramah. Guru sebaiknya menggunakan fasilitas dan sumber belajar yang lebih baik lagi dan guru sebaiknya memperbaiki cara mengajar, d) Model pembelajaran yang digunakan guru matematika masih belum bervariasi umumnya guru mengajar dengan metode ceramah. Kemampuan pedagogik guru juga masih minim, kegiatan pembelajaran yang dilakukan masih konvensional, siswa hanya pasif sebagai pendengar. Pembelajaran umumnya satu arah dimana guru memberikan atau menyalin materi atau rumus-rumus, memberikan contoh soal matematika dan dilanjutkan dengan tugas di kelas atau di rumah..Pembelajaran tidak sepenuhnya

Arif Pribadi, Humuntal Banjarnahor. Perbedaan Kemampuan Pemahaman Konsep Matematika Siswa dengan Model Pembelajaran Kontekstual dan Model Pembelajaran Investigasi Kelompok Kelas VIII SMP Negeri 1 Pancur Batu. Jurnal Inspiratif, Vol. 3 No. 3 Desember 2017. 
mengacu pada RPP yang ada, menurut guru ini terjadi karena keterbatasan alat. Hal ini juga menunjukkan bahwa guru juga masih memerlukan pelatihan pengembangan RPP berbasis KTSP, sehingga guru tidak hanya mencontoh RPP dari sumber lain, e) media atau sumber pembelajaran yang digunakan dalam pembelajaran matematika juga kurang maksimal. Guru-guru hanya berorientasi pada buku paket yang ada. Tes yang dilakukan dalam pembelajaran juga kurang standar. Guru kurang menerapkan authentic assessment seperti penilaian project, unjuk kerja dan lain-lain. Sehingga ujian yang dilakukan guru-guru berada di bawah standar UN dan terdapat perbedaan yang signifikan antara nilai ujian ulangan yang diberikan guru dengan nilai UN siswa.

\section{KESIMPULAN}

Dari hasil analisis yang dilakukan dalam penelitian ini diperoleh kesimpulan sebagai berikut :

1. Hasil uji hipotesis memberikan nilai $t_{\text {hitung }}=1,734252$ dan $t_{\text {tabel }}=$ 1,6693 dengan $\mathrm{dk}=64$ dan taraf signifikan $\alpha=0,05$ sehingga terlihat $\quad t_{\text {hitung }}(1,734252)>$ $t_{\text {tabel }}(1,6693)$ yang berarti bahwa $\mathrm{H}_{\mathrm{o}}$ ditolak dan $\mathrm{H}_{\mathrm{a}}$ diterima. Sehingga disimpulkan bahwa kemampuan pemahaman konsep matematika siswa yang diajar menggunakan model pembelajaran kontekstual (CTL) lebih baik daripada kemampuan pemahaman konsep matematika siswa yang diajar menggunakan model pembelajaran Investigasi Kelompok (Group Investigation) di kelas VIII SMP Negeri 1 Pancur Batu T.A 2016/2017. Begitu pula dengan rata-rata nilai posttest kemampuan pemahaman konsep sebesar 77,171 pada kelas
Eksperimen 1 dan 70,685 pada kelas eksperimen 2.

2. Nilai rata-rata per indikator pada kelas yang menggunakan model pembelajaran kontekstual (CTL) berada pada rentang 70,00-84,99. Sehingga dapat disimpulkan bahwa tingkat pemahaman konsep matematika siswa pada model pembelajaran kontekstual (CTL) tergolong baik. Sedangkan pada kelas yang diajar menggunakan model pembelajaran investigasi kelompok (Group Investigation), nilai rata-rata untuk indikator menyatakan ulang sebuah konsep, memberi contoh dan bukan contoh, serta menyajikan konsep ke dalam berbagai bentuk representasi matematis berada pada rentang 70,00 - 84,99 sehingga tergolong baik. Namun nilai rata-rata pada indikator menggunakan prosedur atau operasi tertentu serta mengaplikasikan konsep ke pemecahan masalah untuk kelas yang diajar menggunakan model pembelajaran Investigasi Kelompok (Group Investigation) berada pada rentang 55,00 - 69,99 sehingga tergolong cukup.

\section{DAFTAR PUSTAKA}

Effendi, L. A., (2012), Pembelajaran Matematika dengan Metode Penemuan Terbimbing untuk Meningkatkan Kemampuan Representasi dan Pemecahan Masalah Matematis Siswa SMP, Jurnal Penelitian Pendidikan, 13 (2), 1-10.

Arif Pribadi, Humuntal Banjarnahor. Perbedaan Kemampuan Pemahaman Konsep Matematika Siswa dengan Model Pembelajaran Kontekstual dan Model Pembelajaran Investigasi Kelompok Kelas VIII SMP Negeri 1 Pancur Batu. Jurnal Inspiratif, Vol. 3 No. 3 Desember 2017. 
Fathurrohman, M., (2015), Model-Model Pembelajaran Inovatif, Ar-Ruzz Media, Jogjakarta.

Murizal, A., Yarman., Yerizon., (2012), Pemahaman Konsep Matematis dan Model Pembelajaran Quantum Teaching, Jurnal Pendidikan Matematika, 1 (1), 19-23.

Surya, E., Sabandar, J., Kusumah, Y.S., and Darhim. (2013). Improving of Junior High School Visual Thinking Representation Ability in Mathematical Problem Solving by CTL. IndoMS. J.M.E, Vol. 4 No. 1, pp. 113-126.

Surya, E., 2013. Analisis Pemetaan dan Pengembangan Model Pembelajaran Matematika SMA di Kabupaten Tapteng dan Kota Sibolga Sumatera Utara. Paradikma Jurnal Pendidikan Matematika, Vol 6 Nomor 1, hal 75-88.

Susanto, A.., (2014), Teori Belajar dan Pembelajaran di Sekolah Dasar,
Kencana Prenadamedia Group, Jakarta.

Trianto, (2014), Mendesain Model Pembelajaran Inovatif, Progresif dan Kontekstual, Prenadamedia Group, Jakarta.

Wardani, S., (2008), Analisis SI dan SKL Mata Pelajaran Matematika SMP/MTs untuk Optimalisasi Tujuan Mata Pelajaran Matematika, Pusat Pengembangan dan Pemberdayaan Pendidik dan Tenaga kependidikan Matematika, Yogyakarta.

Wulandari, I. C., Turmudi., Hasanah, A.., (2015), Studi Cross-Sectional Tingkat Kemampuan Literasi Matematis Siswa Sekolah Menengah Pertama di Bandung Berdasarkan Pengujian Soal PISA, Jurnal Lingkar Widyaiswara, 2 (3), 10-25 